\title{
Influence of diet and $\beta$-agonist administration on plasma concentrations of growth hormone and insulin-like growth factor-1 in young steers
}

\author{
BY J. M. DAWSON' ${ }^{1}$ J. CRAIGON', P. J.BUT,TERY1 AND D. E. BEEVER ${ }^{2}$ \\ ${ }^{1}$ Department of Applied Biochemistry and Food Science, Faculty of Agricultural and Food Sciences, \\ University of Nottingham Sutton Bonington Campus, Loughborough, Leicestershire LE12 5RD \\ ${ }^{2}$ Department of Ruminant Nutrition and Metabolism, AFRC Institute for Grassland and \\ Environmental Research, Hurley, Maidenhead, Berkshire SL6 SLR
}

(Received 17 June 1991-Accepted 3 September 1992)

\begin{abstract}
The effect of feeding grass silage or a forage-concentrate (dried grass-barley) diet ad lih. to young cattle on growth rate, plasma growth hormone (GH) and insulin-like growth factor-1 (IGF-1) concentrations was examined. The effect of including the $\beta$-adrenergic agonist cimaterol in the forage-concentrate diet was also investigated. Significantly higher growth rates were observed in animals fed on the forage-concentrate diet than in those fed on the silage diet $(P<0.001)$, and these were further enhanced by dietary inclusion of cimaterol $(P<0$-05). Plasma GH levels were higher in the silage-fed animals $(P<0.001)$ but IGF-1 levels were significantly lower $(P<0.001)$ than in the forage-concentrate-fed animals. Cimaterol had no effect on mean plasma GH and IGF-1 concentrations. Nevertheless, plasma IGF-1 levels correlated positively with growth rate across all three treatments $(r 0.84, P<0.001, n 17)$. Spectral analysis of the GH data obtained for each animal was used to determine whether regular periodicities could be detected in the $24 \mathrm{~h}$ profile and whether they differed between the three treatment groups. Regular periodicities of four-five cycles/d were detected in the averaged GH profiles of the silage-fed and the control forage-concentrate-fed animals. In contrast, in animals given cimaterol regular GH cycles were not detectable at any of the frequencies tested. This suggests that cimaterol disrupts the rhythm of GH secretion without altering the overall mean concentrations. The data also suggest that due to an inadequate nutrient supply, the GH-IGF-1 regulatory mechanism was uncoupled in the cattle fed on silage, which may have contributed to the poor growth response of these animals.
\end{abstract}

Spectral analysis: Growth hormone: Insulin-like growth factor-1 : Forage: Bovidae

Whilst growth hormone $(\mathrm{GH})$ is recognized as essential for normal postnatal development in mammalian species, circulating concentrations do not always correlate positively with growth rate (Wheaton et al. 1986). This, in part, may be related to the suggestion that the anabolic effects of GH are largely mediated by insulin-like growth factor-1 (IGF-1), but nutritional status also plays a major role in determining circulating GH concentrations and appears to have a dominant influence on the hepatic response to GH. Elevated concentrations of $\mathrm{GH}$ have been reported in a number of species including man (Merimee \& Finberg, 1974), dogs (Eigenmann et al. 1985), sheep (Driver et al. 1976) and cattle (Breier et al. 1986) during periods of starvation or restricted food intake, while plasma IGF-1 levels are often significantly reduced under such conditions (Clemmons et al. 1981; Breier et al. 1986).

In a study of growth and development in cattle the effects of diet (grass silage or forage concentrate) and a repartitioning agent ( $\beta$-adrenergic agonist) were investigated. The effects of both diet and the $\beta$-agonist were dramatic, causing growth rate to increase 
by 0.4 and $0.7 \mathrm{~kg} / \mathrm{d}$ respectively, with significant changes in the contents of protein and fat in the carcass. As part of this study serial blood sampling was undertaken to determine daily patterns of plasma $\mathrm{GH}$ concentrations. The objective of this study was to examine the $24 \mathrm{~h}$ profiles of GH concentrations using spectral analysis, as described by Howles et al. (1982), in order to establish and identify the pattern of GH secretion and consider how this may influence the anabolic responses obtained.

\section{METHODS}

Animals and experimental procedure

Eighteen Friesian steers (12 weeks of age, average initial live weight 92 (SD 3) kg) were allocated to the experiment. They comprised three equal batches, with each batch separated in age by 2 weeks. The experiment consisted of three treatments such that two animals from each batch were allocated at random to each treatment, giving a total of six animals per treatment. The treatments comprised (1) grass silage, (2) dried grass-barley pellets $(70: 30$, $\mathrm{w} / \mathrm{w})$ and (3) dried grass - barley pellets $(70: 30, \mathrm{w} / \mathrm{w})$ containing the $\beta$-adrenergic agonist cimaterol at $1.5 \mathrm{mg} / \mathrm{kg}$ diet. All diets were offered ad lib. with feed refusals measured daily. Animals were penned in pairs according to treatment group and batch, and total daily feed intake per pen was measured. Live weights were recorded weekly for 16 weeks.

When the cattle reached 23 weeks of age they were transferred to individual stalls and maintained on their respective treatments. The left jugular vein of each animal was cannulated after $5 \mathrm{~d}$ with a sterile polyurethane catheter $(1.2 \mathrm{~mm}$ internal diameter; British Viggo, Swindon, Wilts) and on the next day blood samples $(10 \mathrm{ml})$ were taken hourly for $25 \mathrm{~h}$ and collected into tubes containing $50 \mathrm{IU}$ heparin kept on ice. After mixing by inversion, samples were centrifuged at $1000 \mathrm{~g}$ for $15 \mathrm{~min}$ and the plasma was removed and stored at $-40^{\circ}$ until analysed.

One animal from the control forage-concentrate group died at 22 weeks of age from pneumonia. All data from this animal have been omitted.

\section{Hormone assays}

GH concentrations were determined on each sample by double antibody radioimmunoassay as described by Pell et al. (1990). In addition, IGF-1 concentrations were determined on pooled $24 \mathrm{~h}$ samples for each animal after acid-ethanol extraction (Pell et al. 1990).

\section{Diet analysis}

The chemical composition of the silage and forage-concentrate diets (Table 1) was determined as described by England \& Gill (1983). All values were corrected for dry matter (DM) determined either by oven drying at $100^{\circ}$ for $16 \mathrm{~h}$ (forage-concentrate diets) or by distillation with toluene (silage) (Dewar \& McDonald, 1961).

\section{Data analysis}

The effect of diet and cimaterol on live-weight gain and $24 \mathrm{~h}$ mean plasma GH and IGF-1 concentrations was examined by two-way analysis of variance with three treatments, three batches and two replicates per batch. The effect of treatment on voluntary food intake was examined as above with one replicate per batch.

The mean $24 \mathrm{~h}$ plasma concentration and standard deviation of GH and IGF-1 were calculated for each animal. Baseline GH concentration was defined as the mean of the lowest four concentrations detected over the $24 \mathrm{~h}$ period, while all concentrations greater than 1 SD above baseline were considered to be part of a GH peak. A drop of at least $1 \mathrm{SD}$ 
Table 1. Chemical composition $(\mathrm{g} / \mathrm{kg}$ dry matter $(D M))$ of the silage and dried grass-barley diets

\begin{tabular}{lcc}
\hline & Silage & Dried grass-barley \\
\hline DM (g/kg fresh diet) & $247^{*}$ & 911 \\
Total N & $19 \cdot 7$ & $27 \cdot 4$ \\
Ammonia-N (g/kg total N) & $94 \cdot 1$ & $\mathrm{ND}$ \\
Total organic acidst & $109 \cdot 6$ & $\mathrm{ND}$ \\
Lactic acid & $87 \cdot 5$ & $\mathrm{ND}$ \\
Neutral-detergent fibre & 563 & 405 \\
Ash & $70 \cdot 5$ & $96 \cdot 7$ \\
pH & $3 \cdot 7$ & $\mathrm{ND}$ \\
Metabolizable energy (MJ/kg DM) $\ddagger$ & $10 \cdot 17$ & $10 \cdot 68$ \\
\hline
\end{tabular}

ND, not determined

* Toluene DM, corrected for ethanol content.

$\dagger$ Acetic, propionic, iso-butyric, $n$-butyric and lactic acids.

\$ Calculated from proximate analysis.

was required to separate GH pulses. Using these criteria, the number of pulses over the $24 \mathrm{~h}$ sampling period was determined for each animal and the mean peak height, peak amplitude and baseline concentrations were subjected to analysis of variance to compare the GH profiles of the three treatment groups.

Spectral analysis, as described by Howles et al. (1982), was also used to examine the $24 \mathrm{~h}$ profiles of GH secretion for periodicities. In essence, this technique describes the hormone profile as the sum of a number of sine waves (McLeod \& Craigon, 1985). Each wave has its own frequency, phase and amplitude with the frequencies equally spaced over the range $0-0.5$ cycles per $h$. Thus, the variation in the original data can be partitioned amongst waves of discrete frequencies with the variation attributable to a particular wave being called the spectral density for that frequency (Diggle, 1990).

Spectral density estimates were calculated by Fourier transformation of autocorrelation coefficients. Autocorrelation coefficients are determined from sequences of $\mathrm{GH}$ concentrations, which are shifted along the profile by fixed intervals and then correlated with later sequences according to the following formula:

$$
r_{k}=\frac{\sum_{i=1}^{N-k}\left(x_{i}-\bar{x}\right)\left(x_{i+k}-\bar{x}\right)}{\sum_{i=1}^{N}\left(x_{i}-\bar{x}\right)^{2}},
$$

where $r_{k}$ is the autocorrelation coefficient for lag period of length $k, x_{i}$ is the GH sample for hour $i$, and $N$ is the total number of samples in a profile.

The normalized spectral density is then calculated as the Fourier transformation of the autocorrelation for a series of frequencies:

$$
S_{j}=\left(1+2 \sum_{i=1}^{N-1} r_{i} \cos \left(\tilde{\omega}_{j} i\right)\right)
$$

where $S_{j}$ is the normalized spectral density estimate at frequency $\tilde{\omega}_{j}, r_{i}$ is the autocorrelation coefficient for lag $i, N$ is the number of samples in the profile, and $\tilde{\omega}_{j}$ is the $j$ th Fourier frequency (i.e. corresponds to $j / N$ cycles per h).

Normalized spectral density estimates plotted over a range of frequencies produce a 
curve comprising a variable number of peaks and troughs. Clearly defined peaks at particular frequencies indicate dominant cycles of that frequency which may be obscure in the original data.

Spectral density estimates as calculated above may have considerable error associated with them which can be reduced by smoothing (Jenkins \& Watts, 1968). Therefore, for each data set the calculations were repeated at three lags using the Parzen smoothing window (Diggle, 1990):

$$
S_{K j}=\left(1+2 \sum_{i=1}^{K-1} r_{i} W_{i} \cos \left(\tilde{\omega}_{j} i\right)\right)
$$

where

$$
W_{i}=1-6\left(\frac{i}{K}\right)^{2}+6\left(\frac{i}{K}\right)^{3} \quad \text { when } \quad\left(i \leqslant \frac{K}{2}\right)
$$

and

$$
W_{i}=2\left(1-\frac{i}{K}\right)^{3} \text { when } \quad\left(\frac{K}{2}<i<K\right) .
$$

$S_{K j}$ is the smoothed normalized spectral density estimate at frequency $\tilde{\omega}_{j}$ and lag $K, r_{i}$ is the autocorrelation coefficient for lag $i, K$ is the smoothing lag, $W_{i}$ is the Parzen weighting factor for the autocorrelation coefficient, and $\tilde{\omega}_{j}$ is the $j$ th Fourier frequency (i.e. corresponds to $j / N$ cycles per h).

These time series calculations were conducted using the Genstat 5 statistical package (Digby et al. 1989). The greater the lag, the greater the degree of smoothing and the narrower the confidence limits on the spectral density estimates become. The penalty for this increased confidence, however, is a reduced ability to discriminate between cycles of similar frequencies. The plots for the three bandwidths were scanned for consistent peaks which were then tested using the method of Rahe et al. (1980).

The hypothesis of no periodicity is rejected $(P<0.05)$ when comparing smoothed with unsmoothed spectral density estimates for a particular frequency if:

$$
\frac{S_{K j}}{S_{j}}<\frac{1}{3}\left(1+\frac{3}{2} \frac{K}{N}\right)
$$

The use of consistent peaks avoids spurious peaks, associated with the unsmoothed spectrum or with just one smoothing bandwidth, being considered as representing true cycles in the data.

To compare the periodicities of the three treatment groups, the smoothed, normalized spectral density estimates calculated at frequencies from 0 to 12 cycles per $d(0$ to 0.5 cycles per $h$ ) for each animal were analysed by fitting a generalized linear model assuming gamma errors and logarithmic link (Diggle, 1990). Analysis of deviance was used to compare the average spectral densities for the three treatment groups at each frequency with the variability between animals on the same treatment (Payne et al. 1988).

\section{RESULTS}

The silage offered in the present experiment was of good quality (Table 1) but estimated daily voluntary feed intake was low $(17.2 \mathrm{~g} \mathrm{DM} / \mathrm{kg}$ live weight $)$ and the resultant growth rate of animals on this diet was disappointing $(0.42 \mathrm{~kg} / \mathrm{d})$. Metabolizable energy (ME) contents of the silage and the dried grass-barley diet, calculated from the proximate 
Table 2. The effect of diet and the dietary inclusion of a $\beta$-adrenergic agonist, cimaterol*, on the growth rate, feed intake and mean growth hormone $(G H)$ and insulin-like growth factor-l (IGF-1) concentrations in young cattle $\dagger$

\begin{tabular}{|c|c|c|c|c|c|c|}
\hline & \multirow[b]{2}{*}{ Silage } & \multicolumn{2}{|c|}{ Dried grass-barley } & \multirow[b]{2}{*}{$\begin{array}{l}\text { Pooled } \\
\text { SED }\end{array}$} & \multicolumn{2}{|c|}{$\begin{array}{l}\text { Statistical significance } \\
\text { ( } P \text { values) effect of }\end{array}$} \\
\hline & & $\begin{array}{l}\text { Without } \\
\text { cimaterol }\end{array}$ & $\begin{array}{l}\text { With } \\
\text { cimaterol }\end{array}$ & & Diet & Cimaterols \\
\hline $\begin{array}{l}\text { Daily live-weight } \\
\text { (LW) gain }(\mathrm{kg} / \mathrm{d})\end{array}$ & 0.42 & 0.86 & $1 \cdot 13$ & $0 \cdot 10$ & $<0.001$ & 0.020 \\
\hline $\begin{array}{l}\text { Total feed intake } \\
\text { (g DM/kg LW per d) }\end{array}$ & $17 \cdot 2$ & 26.5 & 29.6 & 1.05 & $<0.001$ & 0.045 \\
\hline $\begin{array}{l}\text { Total ME intake } \\
\text { (MJ/kg LW per d) }\end{array}$ & 0.18 & $0 \cdot 28$ & $0 \cdot 32$ & 0.011 & $<0 \cdot 001$ & 0.049 \\
\hline $\begin{array}{l}\text { Total N intake } \\
\text { (g/kg LW per d) }\end{array}$ & $0 \cdot 34$ & 0.73 & 0.81 & 0.029 & $<0.001$ & 0.046 \\
\hline $\begin{array}{l}\text { Mean GH concentration } \\
(\mathrm{ng} / \mathrm{ml})\end{array}$ & $11 \cdot 7$ & $5 \cdot 93$ & $6 \cdot 45$ & 0.88 & $<0.001$ & $>0.05$ \\
\hline $\begin{array}{l}\text { Mean IGF-1 concentration } \\
(\mathrm{ng} / \mathrm{ml})\end{array}$ & 118 & 374 & 381 & $42 \cdot 4$ & $<0.001$ & $>0.05$ \\
\hline
\end{tabular}

SED, Standard error of difference between means (df 12, except total feed intake (residual df 4)); DM, dry matter; ME, metabolizable energy.

* For details of diets, see p. 94 and Table 1.

$\dagger$ For details of procedures, see p. 94.

\$ Statistical analysis of silage and dried grass-barley (without cimaterol)

$\S$ Statistical analysis of dried grass-barley without and with cimaterol.

analyses, were very similar (10.2 and $10.7 \mathrm{MJ} / \mathrm{kg} \mathrm{DM}$ respectively), but the forageconcentrate pellets had a significantly higher crude protein content $(171 \mathrm{~g} / \mathrm{kg}$ DM compared with $123 \mathrm{~g} / \mathrm{kg} \mathrm{DM}$; Table 1) and this may in part have contributed to the higher feed intakes $(26.5 \mathrm{~g} / \mathrm{kg}$ live weight per $\mathrm{d})$ and live weight gains $(0.86 \mathrm{~kg} / \mathrm{d})$ noted on this diet. Inclusion of cimaterol in the diet resulted in a further increase in growth rate $(1.13 \mathrm{~kg} / \mathrm{d})$, accompanied by a further increase in feed consumption $(29.6 \mathrm{~g} / \mathrm{kg}$ live weight per d). These data are summarized in Table 2, along with mean daily plasma GH and IGF-1 concentrations for the three treatments. GH concentrations were significantly elevated in the silage-fed animals $(P<0.001)$, which showed the lowest rate of gain whilst IGF-1 concentrations were significantly reduced $(P<0.001)$. Comparison of the effect of cimaterol on GH and IGF-1 concentrations in cattle receiving the forage-concentrate diet revealed no significant differences $(P>0 \cdot 1)$. Plasma IGF-1 levels correlated positively with growth rate over all three groups $(r 0.84, P<0.001, n 17)$.

Table 3 shows profile summaries for GH secretion for the three treatment groups. According to our definition of a GH peak, all of the animals showed three or four peaks over the $24 \mathrm{~h}$ period but three of the cimaterol-treated animals showed six or seven peaks. Mean baseline GH concentration was significantly higher $(P<0.001)$ in the silage-fed animals compared with the two forage-concentrate-fed groups which were not different $(P>0.05)$. Mean peak height was also higher for the silage-fed animals $(P<0.01)$ while again no difference was found between the other two groups $(P>0.05)$. No differences, however, were found between the mean peak amplitudes in any of the three treatment groups $(P>0 \cdot 05)$.

Fig. 1 shows the logarithm of the spectral density estimates combined for all the animals in each of the three treatment groups, plotted $v$. frequency. The plots for the silage- and 
Table 3. Variables of plasma growth hormone $(G H)$ profiles in young steers fed either grass silage, or a forage-concentrate diet without and with the inclusion of cimaterol at $1.5 \mathrm{mg} / \mathrm{kg}^{*}$

\begin{tabular}{|c|c|c|c|c|c|c|}
\hline & \multirow[b]{2}{*}{ Silage } & \multicolumn{2}{|c|}{ Dried grass-barley } & \multirow[b]{2}{*}{$\begin{array}{l}\text { Pooled } \\
\text { SED }\end{array}$} & \multicolumn{2}{|c|}{$\begin{array}{l}\text { Statistical significance } \\
(P \text { values }) \text { effect of }\end{array}$} \\
\hline & & $\begin{array}{l}\text { Without } \\
\text { cimaterol }\end{array}$ & $\begin{array}{l}\text { With } \\
\text { cimaterol }\end{array}$ & & $\operatorname{Diet} \ddagger$ & Cimaterol\$ \\
\hline $\begin{array}{l}\text { Baseline GH concentration } \\
(\mathrm{ng} / \mathrm{ml})\end{array}$ & $4 \cdot 33$ & 0.47 & $1 \cdot 22$ & 0.88 & $<0.001$ & $>0.05$ \\
\hline $\begin{array}{l}\text { Mean peak height } \\
(\mathrm{ng} / \mathrm{ml})\end{array}$ & 16.92 & $12 \cdot 31$ & $11 \cdot 71$ & $1 \cdot 50$ & $<0.01$ & $>0.05$ \\
\hline $\begin{array}{l}\text { Mean amplitude } \\
(\mathrm{ng} / \mathrm{ml})\end{array}$ & $12 \cdot 59$ & $11 \cdot 84$ & $10 \cdot 49$ & 1.47 & $>0.05$ & $>0.05$ \\
\hline
\end{tabular}

SED, Standard error of difference between means (df 14).

* For details of diets, see p. 94 and Table 1; for details of procedures, see pp. 9495.

$\uparrow$ Statistical analysis of silage and dried grass-barley without cimaterol.

\$ Statistical analysis of dried grass-barley without and with cimaterol.

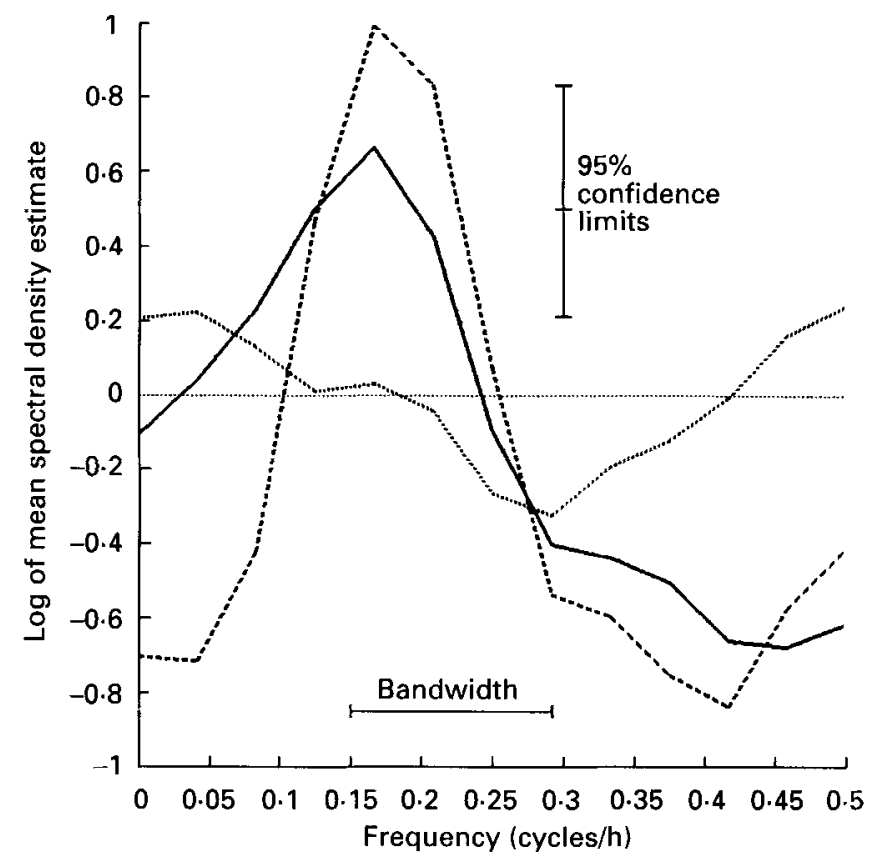

Fig. 1. Logarithms of the combined spectral density estimates of growth hormone profile for animals in the silage $(-)$, forage-concentrate without cimaterol (--.) and forage-concentrate with cimaterol (......) groups $v$. frequency. For details of procedures, see pp. $95-96$.

control forage-concentrate-fed animals each show a single peak at a frequency between $0 \cdot 15$ and $0 \cdot 2$ cycles per $h$ while for the cimaterol-treated animals, no peak was discernible at any of the frequencies plotted. As the confidence limits, when centred on the spectral density peaks of the silage-fed and control forage-concentrate-fed animals, would not descend to zero, these peaks indicate a true $\mathrm{GH}$ periodicity of four to five cycles per $24 \mathrm{~h}$ 
in these data. Analysis of deviance for the spectral density estimates confirmed that the $\mathrm{GH}$ periodicity differed between the cimaterol-treated and the other groups $(P<0.001)$. No interaction between the two dietary groups (silage and forage-concentrate) and frequency $(P>0.05)$ was detected.

Assessment of the individual spectral density plots for all seventeen animals, using the three bandwidths, showed that for ten of the eleven animals in the silage and control forage-concentrate groups cyclic behaviour with a frequency around $0 \cdot 18$ cycles per $h$ was detected $(P<0.05)$, whereas only one animal in the cimaterol-treated group showed any evidence of a cycle at this frequency. The one animal from the silage group in which a cycle was not detected had the highest growth rate of its group $(0.58 \mathrm{~kg} / \mathrm{d})$ and the highest mean $\mathrm{GH}$ level $(15 \cdot 1 \mathrm{ng} / \mathrm{ml})$. In contrast, the one cimaterol-treated animal which showed $\mathrm{GH}$ cycles had the lowest growth rate and plasma GH level of its group (DLWG $0.85 \mathrm{~kg} / \mathrm{d}, \mathrm{GH}$ $5 \cdot 2 \mathrm{ng} / \mathrm{ml})$.

\section{DISCUSSION}

Animals fed on the forage-concentrate diet showed significantly higher growth rates than animals fed on grass silage despite both diets being fed ad lib. Growth rates correlated positively with plasma IGF-1 levels in these two treatment groups, in agreement with the observations of Breier et al. (1988a), whilst GH levels were inversely related. Nutrition is known to have a modulating effect on GH and IGF-1 secretion in many species, with GH levels tending to increase and IGF-1 levels tending to be reduced by starvation or low levels of feeding (Eigenmann et al. 1985; Breier et al. 1986). Increased GH levels under these conditions are suggested to occur as a result of either reduced metabolic clearance of GH (Trenkle, 1976) or of altered feedback mechanisms (Mounier et al. 1989), while the liver responsiveness to $\mathrm{GH}$ tends to become markedly reduced resulting in low levels of IGF-1 production. This has been shown to be associated with changes in GH receptor affinity, the presence of high-affinity binding sites which correlate with weight gain and plasma IGF-1 concentration only being detectable in well-fed animals (Breier et al. 1988b). Metabolic clearance rate of plasma IGF-1, however, may also be enhanced in malnourished animals (Breier \& Gluckman, 1991) resulting in low plasma concentrations. In the present experiment the silage-fed animals showed positive growth rates $(0.42 \mathrm{~kg} / \mathrm{d})$, but $\mathrm{GH}$ levels were significantly elevated and IGF-1 levels were significantly depressed compared with animals fed on the forage-concentrate diet suggesting that the GH-IGF-1 regulatory mechanism had been uncoupled. Several reasons have been put forward to explain the poor productivity of silage-fed cattle, including impaired intake (Marsh, 1979) and limited protein supply (Gill et al. 1987). Results from the present experiment further suggest that protein or energy supply, or both, was sufficiently limited to make these animals behave as undernourished animals despite being fed ad lib. and showing positive growth rates. Recent investigations into the effect of varying degrees of protein and energy restriction on plasma IGF-1 levels in cattle have suggested that dietary protein level may be the primary determinant of the circulating concentration, but that the IGF-1 response to protein may be affected by the available energy (Ronge et al. 1988; Elsasser et al. 1989).

Breier et al. (1986) reported that the baseline GH concentration and the number of GH peaks did not change significantly with reduced feed intake, but that peak height and area under the GH pulses increased. Houseknecht et al. (1988) observed a similar effect in cattle fed on a low-energy diet but reported that baseline GH concentration was increased as well as peak amplitude. Our results indicate an elevated baseline concentration of GH in the silage-fed animals relative to those fed on the forage-concentrate diet, but similar peak amplitudes and periodicities were observed in animals fed on both diets. Thus, these results suggest that the higher average GH concentrations seen in the silage-fed animals were not 
the result of more frequent releases nor due to a greater release of GH with each episode, but that metabolic clearance rate may have been reduced. Elsasser et al. (1989) reported a significant effect of dietary protein level on the number of secretory spikes of GH. These authors took more frequent samples than in the present experiment, but only over a $6 \mathrm{~h}$ period. We observed no difference in the number of $\mathrm{GH}$ peaks between the silage- and forage-concentrate-fed animals. It is possible, however, that more frequent releases of GH would not be detected with the frequency of blood sampling used in the present study. More frequent sampling would have enhanced the detection of individual episodes, the variables (baseline, peak height and amplitude) that are based upon them, and would enable a more robust definition of a GH pulse to be used. The summary measures of GH secretion given in the present study should, therefore, only be considered as a broad description of the differences between treatment groups. A greater number of $\mathrm{GH}$ surges than those detected in the present experiment have been recorded in cattle by workers sampling at 10-20 min intervals e.g. 0.31/h (Moseley et al. 1982), 0.5-0.75/h (Wheaton et al. 1986), 0.41-0.46/h (Breier et al. 1988a) and 0.48-0.78/h (Elsasser et al. 1989). Nevertheless, distinct secretory episodes of $\mathrm{GH}$ at approximately $4-6 \mathrm{~h}$ intervals are also apparent in some of these profiles (Moseley et al. 1982; Breier et al. 1986; Wheaton et al. 1986) indicating a $\mathrm{GH}$ periodicity of 46 cycles/d, similar to that determined in the present experiment. The physiological significance of this periodicity of GH secretion remains to be elucidated.

Inclusion of cimaterol in the forage-concentrate diet caused a further increase in liveweight gain over the control forage concentrate group but no significant changes in plasma $\mathrm{GH}$ or IGF-1 concentrations. At the same time, small but significant increases in metabolizable energy and $\mathrm{N}$ intakes were observed in response to the dietary inclusion of cimaterol which undoubtedly contributed to the increased live-weight gain noted. The mechanism by which cimaterol increased feed intake is not known and the issue is further confused by several reports which suggest the $\beta$-adrenergic agonists may in fact reduce feed intake (Reeds \& Mersmann, 1991) although variations in dose rate and species may account for this paradox. $\beta$-agonists routinely increase the rate of protein accretion and reduce fat deposition, changes which may also result in an overall increase in live-weight gain depending on the relative rates at which the two processes are affected. The exact mode of action of the $\beta$-agonists is still not fully understood but changes in the endogenous endocrine system or tissue sensitivity to some hormones have been postulated as having a possible role in mediating the dramatic effects of these agents (Buttery \& Dawson, 1987). There are few reports of the effects of $\beta$-adrenergic agonists on the somatotropic axis and although some early workers suggested that the repartitioning effect of $\beta$-agonists may be mediated via an increase in GH secretion (Ricks et al. 1984) more recent studies have found little evidence for any involvement in their mode of action (Maltin et al. 1990). Few studies have reported a significant increase in plasma GH concentration in animals treated with $\beta$ agonists, although in vitro work has clearly shown a direct stimulation of $\mathrm{GH}$ release from cultured adenohypophyseal cells (Welsh et al. 1987) and perifused putuitary cells (Perkins et al. 1983) on administration of $\beta$-adrenergic agonists. As neither mean GH or IGF-1 levels were significantly altered in the $\beta$-agonist-treated animals in the present experiment despite growth rates being significantly higher, this suggests that the effects of cimaterol were not mediated directly through increased GH secretion or increased IGF-1. Interestingly, however, compared to control animals, the periodicity of GH secretion was disrupted. This suggests that cimaterol in some way altered the rhythm of GH secretion. From the present results it is not possible to determine whether the inherent periodicity is lost completely or whether the episodes are more frequent and remained undetectable with the sampling regime used. However, the fact that the inherent pulsatility of GH secretion 
can be altered by drug administration gives rise to the possibility that other processes may also be affected. Further work is obviously required to elucidate the physiological significance of such changes and their involvement in the mechanism of action of $\beta$ agonists.

The authors are grateful to Boehringer Ingelheim Vetmedica for supplying the cimaterol and to Alan Simmonds and John Paradine at the Institute for Grassland and Environmental Research for the GH and IGF-1 assays. This work is supported by an Agricultural and Food Research Council linked-research grant.

\section{REFERENCES}

Breier, B. H., Bass, J. J., Butler, J. H. \& Gluckman, P. D. (1986). The somatotrophic axis in young steers: influence of nutritional status on pulsatile release of growth hormone and circulating concentrations of insulinlike growth factor-1. Journal of Endocrinology 111, 209-215.

Breier, B. H. \& Gluckman, P. D. (1991). The regulation of post-natal growth - nutritional influences on endocrine pathways and function of somatotrophic axis. Livestock Production Science 27, 77-94.

Breier, B. H., Gluckman, P. D. \& Bass, J. J. (1988a). Influence of nutritional status and oestradiol-17 $\beta$ on plasma growth hormone, insulin-like growth factors-I and -II and the response to exogenous growth hormone in young steers. Journal of Endocrinology 118, 243-250.

Breier, B. H., Gluckman, P. D. \& Bass, J. J. (1988b). The somatotrophic axis in young steers: influence of nutritional status and oestradiol- $17 \beta$ on hepatic high- and low-affinity somatotrophic binding sites. Journal of Endocrinology 116, 169-177.

Buttery, P. J. \& Dawson, J. M. (1987). The mode of action of beta-agonists as manipulators of carcass composition. In Beta-Agonists and their Effects on Animal Growth and Carcass Quality, pp. 29-43 [J. P. Hanrahan, editor]. London: Elsevier Applied Science.

Clemmons, D. R., Klibanski, A., Underwood, L. E., McArthur, J. W., Ridgway, E. C., Beitius, J. Z. \& Van Wyk, J. J. (1981). Reduction of plasma immunoreactive somatostatin C during fasting in humans. Journal of Clinical Endocrinology and Metabolism 53, 1247-1250.

Dewar, W. A. \& McDonald, P. (1961). Determination of dry matter in silage by distillation with toluene. Journal of the Science of Food and Agriculture 12, 790-795.

Digby, P., Galway, N. \& Lane, P. (1989). Genstat 5, A Second Course. Oxford: Oxford Science Publications.

Diggle, P. J. (1990). Time Series, A Biostatistical Introduction. Oxford: Oxford Science Publications.

Driver, P. M., Brown, W. B., Scanes, C. G. \& Forbes, J. M. (1976). Serum growth hormone levels in growing lambs at two daylengths and two levels of feeding. Journat of Endocrinology 69, 44P-45P.

Eigenmann, J. E., de Bruijne, J. J. \& Froesch, E. R. (1985). Insulin-like growth factor-1 and growth hormone in canine starvation. Acta Endocrinologica 108, 161-166.

Elsasser, T. H., Rumsey, T. S. \& Hammond, A. C. (1989). Influence of diet on basal and growth hormonestimulated plasma concentrations of IGF-1 in beef cattle. Joumal of Animal Science 67, 128-141.

England, P. \& Gill, M. (1983). The effect of wilting and short-chopping of grass on the subsequent voluntary intake of silage, and liveweight gain of calves. Animal Production 36, 73-77.

Gill, M., Beever, D. E., Buttery, P. J., England, P., Gibb, M. J. \& Baker, R. D. (1987). The effect of oestradiol$17 \beta$ implantation on the response in voluntary intake, liveweight gain and body composition, to fishmeal supplementation of silage offered to growing calves. Journal of Agricultural Science, Cambridge 108, 9-16.

Houseknecht, K. L., Boggs, D. L., Campion, D. R., Sartin, J. L., Kiser, T. E., Rampacek, G. B. \& Amos, H. E. (1988). Effect of dietary source and level on serum growth hormone, insulin-like growth factor-1, growth and body composition in beef heifers. Journal of Animal Science 66, 2916-2923.

Howles, C. M., Craigon, J. \& Haynes, N. B. (1982). Long term rhythms of testicular volume and plasma prolactin concentrations in rams reared for 3 years in constant photoperiod. Journal of Reproduction and Fertility $\mathbf{6 5}$, 439- 446 .

Jenkins, C. M. \& Watts, D. G. (1968). The spectrum. In Spectral Analysis and its Applications, pp. 209-257 [G. M. Jenkins and E. Parzen, editors]. San Francisco: Holden-Day.

McLeod, B. J. \& Craigon, J. (1985). Time series analysis of plasma LH and FSH concentrations as a method of assessing episodic secretion. Joumal of Reproduction and Fertility 74, 575-587.

Maltin, C. A., Delday, M. I., Hay, S. M., Innes, G. M. \& Williams, P. E. V. (I990). Effects of bovine pituitary growth hormone alone or in combination with the $\beta$-agonist clenbuterol on muscle growth and composition in veal calves. British Journal of Nutrition 63, 535-545.

Marsh, R. (1979). The effects of wilting on fermentation in the silo and on the nutritive value of silage. Grass and Forage Science 34, 1-10

Merimee, T. J. \& Finberg, S. E. (1974). Growth hormone secretion in starvation: a reassessment. Journal of Clinical Endocrinology and Metabolism 39, 385-386. 
Moseley, W. M., Krabill, L. F. \& Olsen, R. F. (1982). Effect of bovine growth hormone administered in various patterns on nitrogen metabolism in the Holstein steer. Journal of Animal Science 55, 1062-1072.

Mounier, F., Bluet-Pajot, M. T., Durand, D., Kordon, C., Rasolonjanahary, R. \& Epelbaum, J. (1989). Involvement of central somatostatin in the alteration of $\mathrm{GH}$ secretion in starved rats. Hormone Research 31, $266-270$.

Payne, R. W., Lane, P. W., Ainsley, A. E., Bicknell, K. E., Digby, P. G. N., Harding, S. A., Leech, P. K., Simpson, H. R., Todd, A. D., Verrier, P. J.\& Whyte, R. P. (1988). Genstat 5 Reference Manual. Oxford: Oxford University Press.

Pell, J. M., Elcock, C., Harding, R. L., Morrell, D. J., Simmonds, A. D. \& Wallis, M. (1990). Growth, body composition, hormonal and metabolic status in lambs treated long-term with growth hormone. British Journal of Nutrition 63, 431-445.

Perkins, S. N., Evans, W.S., Thorner, M. O. \& Cronin, M. J. (1983). Beta-adrenergic stimulation of growth hormone release from perifused rat anterior pituitary cells. Neuroendocrinology 37, $473-475$.

Rahe, C. H., Owens, R. E., Fleeger, J. L., Newton, H. J. \& Harms, P. G. (1980). Pattern of plasma luteinizing hormone in the cyclic cow: dependence upon the period of the cycle. Endocrinology 107, 498-503.

Reeds, P. J. \& Mersmann, H. J. (1991). Protein and energy requirements of animals treated with beta-adrenergic agonists: a discussion. Journal of Animal Science 69, 1532-1550.

Ricks, C. A., Dalrymple, R. H., Baker, P. K. \& Ingle, D. L. (1984). Use of a $\beta$ agonist to alter fat and muscle deposition in steers. Journal of Agricultural Science 59, 1247-1255.

Ronge, H., Blum, J., Clement, C., Jans, F., Leuenberger, H. \& Binder, H. (1988). Somatomedin C in dairy cows related to energy and protein supply and to milk production. Animal Production 47, 165-183.

Trenkle, A. (1976). Estimates of the kinetic parameters of growth hormone metabolism in fed and fasted calves and sheep. Journal of Animal Science 43, 1035-1043.

Welsh, T. H. Jr, Smith, S. B., Sutton, M. R. \& Wagner, K. A. (1987). Growth hormone releasing factor and clenbuterol regulation of bovine growth hormone secretion in vitro. Journal of Animal Science 65, Suppl. 1, 279.

Wheaton, J. E., Al-Raheem, S. N., Massri, Y. G. \& Marcek, J. M. (1986). Twenty-four-hour growth hormone profiles in Angus steers. Journal of Animal Science 62, 1267-1272. 